\title{
Arsenic trioxide induces apoptosis and the formation of reactive oxygen species in rat glioma cells
}

\author{
Yuanyuan Sun ${ }^{1}$, Chen Wang ${ }^{2}$, Ligang Wang ${ }^{2}$, Zhibo Dai ${ }^{2}$ and Kongbin Yang ${ }^{2 *}$
}

\author{
*Correspondence: dk5732@163. \\ com; ykbnewrosurgery@sina.com \\ ${ }^{2}$ Neurosurgery Department, First \\ Affiliated Hospital, Harbin Medical \\ University, Nangang District, Harbin \\ 150000, China \\ Full list of author information is \\ available at the end of the article
}

\begin{abstract}
Background: Arsenic trioxide $\left(\mathrm{As}_{2} \mathrm{O}_{3}\right)$ has a dramatic therapeutic effect on acute promyelocytic leukemia (APL) patients. It can also cause apoptosis in various tumor cells. This study investigated whether $\mathrm{As}_{2} \mathrm{O}_{3}$ has an antitumor effect on glioma and explored the underlying mechanism.
\end{abstract}

Results: MTT and trypan blue assays showed that $\mathrm{As}_{2} \mathrm{O}_{3}$ remarkably inhibited growth of $\mathrm{C} 6$ and $9 \mathrm{~L}$ glioma cells. Cell viability decreased in glioma cells to a greater extent than in normal glia cells. The annexin V-FITC/PI and Hoechest/PI staining assays revealed a significant increase in apoptosis that correlated with the duration of $\mathrm{As}_{2} \mathrm{O}_{3}$ treatment and occurred in glioma cells to a greater extent than in normal glial cells. $\mathrm{As}_{2} \mathrm{O}_{3}$ treatment induced reactive oxygen species (ROS) production in $\mathrm{C} 6$ and $9 \mathrm{~L}$ cells in a time-dependent manner. Cells pretreated with the antioxidant $\mathrm{N}$-acetylcysteine (NAC) showed significantly lower $\mathrm{As}_{2} \mathrm{O}_{3}$-induced $\mathrm{ROS}$ generation. $\mathrm{As}_{2} \mathrm{O}_{3}$ significantly inhibited the expression of the anti-apoptotic gene $\mathrm{BCl}-2$, and upregulated the proapoptotic gene Bax in both $\mathrm{C} 6$ and $9 \mathrm{~L}$ glioma cells in a time-dependent manner.

Conclusions: $\mathrm{As}_{2} \mathrm{O}_{3}$ can significantly inhibit the growth of glioma cells and it can induce cell apoptosis in a time- and concentration-dependent manner. ROS were found to be responsible for apoptosis in glioma cells induced by $\mathrm{As}_{2} \mathrm{O}_{3}$. These results suggest $\mathrm{As}_{2} \mathrm{O}_{3}$ is a promising agent for the treatment of glioma.

Keywords: Arsenic trioxide $\left(\mathrm{As}_{2} \mathrm{O}_{3}\right)$, Reactive oxygen species (ROS), Glioma, Apoptosis

\section{Background}

Despite commonly being known as a toxic metalloid, arsenic trioxide $\left(\mathrm{As}_{2} \mathrm{O}_{3}\right)$ has applications in traditional medicine in China. As early as the 1970s, a research group at the First Affiliated Hospital of Harbin Medical University discovered that $\mathrm{As}_{2} \mathrm{O}_{3}$ can induce remissions in up to $70 \%$ of acute promyelocytic leukemia (APL) patients $[1,2]$. The dramatic therapeutic effect of $\mathrm{As}_{2} \mathrm{O}_{3}$ on APL was achieved primarily through the induction of cell differentiation and apoptosis [2,3]. At low concentrations, $\mathrm{As}_{2} \mathrm{O}_{3}$ promoted cell differentiation, while at concentrations above $0.5 \mu \mathrm{mol} / \mathrm{l}$, it induced cell apoptosis $[4,5]$.

$\mathrm{As}_{2} \mathrm{O}_{3}$ induced apoptosis not only in NB4 cells (an APL cell line) but also in various other tumor cell lines $[6,7]$. The underlying mechanism remained unclear, but inhibition of cell differentiation and growth and induction of apoptosis are speculated to be

(c) The Author(s). 2018 Open Access This article is distributed under the terms of the Creative Commons Attribution 4.0 International License (http://creativecommons.org/licenses/by/4.0/), which permits unrestricted use, distribution, and reproduction in any medium, provided you give appropriate credit to the original author(s) and the source, provide a link to the Creative Commons license, and indicate if changes were made. The Creative Commons Public Domain Dedication waiver (http://creativecommons.org/ publicdomain/zero/1.0/) applies to the data made available in this article, unless otherwise stated. 
the general mechanisms for tumor treatment [8] and $\mathrm{As}_{2} \mathrm{O}_{3}$ action $[9,10]$. Further research on $\mathrm{As}_{2} \mathrm{O}_{3}$ in APL showed that reactive oxygen species (ROS) play an important role in the induction of apoptosis, and that APL cells are sensitive to the intracellular ROS levels [11]. However, there is still some discussion about whether ROS are involved in $\mathrm{As}_{2} \mathrm{O}_{3}$ inhibition of the growth of tumor cells [11-14].

Due to the existence of the blood-brain barrier, it is hard for therapeutics drugs to affect glioma cells. New therapeutics are required to overcome this challenge. Although it is still unclear how $\mathrm{As}_{2} \mathrm{O}_{3}$ could cross the blood-brain barrier, several studies of $\mathrm{As}_{2} \mathrm{O}_{3}$ in glioma indicate that it is a potential therapeutic agent for this type of cancer $[9,15]$.

The effective concentrations of $\mathrm{As}_{2} \mathrm{O}_{3}$ applied in those studies were extremely high, ranging from $4.0 \mu \mathrm{M}$ to $5.0 \mathrm{mM}[16,17]$. High concentrations of $\mathrm{As}_{2} \mathrm{O}_{3}$ carry a major health risk. Side effects include mild gastrointestinal discomfort, transient elevation of liver enzymes, reversible neuropathy, hypokalemia, hyperglycemia and cardiac toxicity. Prolongation of the life quality has been detected in as many as $38 \%$ of patients treated with $\mathrm{As}_{2} \mathrm{O}_{3}[18,19]$. In this study, we investigated the anti-tumor effect of a low concentration range $(0-8 \mu \mathrm{mol} / \mathrm{l})$ of $\mathrm{As}_{2} \mathrm{O}_{3}$ in the glioma cell lines $\mathrm{C} 6$ and $9 \mathrm{~L}$, assessed changes to non-tumor (glial) cells, and explored the underlying mechanism by studying ROS.

\section{Methods}

\section{Cell culture}

$\mathrm{As}_{2} \mathrm{O}_{3}$ was obtained from Yida. Stock solutions were prepared in phosphate buffered saline (PBS) to exclude any unknown influence from other solvents. Working solutions were diluted in RPMI-1640 medium (Gibco) and Dulbecco's modified Eagle's medium (DMEM; Gibco), supplemented with 10\% heat-inactivated fetal calf serum (FCS).

Rat C6 and $9 \mathrm{~L}$ glioma cells were obtained from Harbin Medical Neurosurgical Institute and were respectively cultured in 10\% RPMI-1640 medium and 10\% DMEM, in both cases supplemented with 10\% FCS. Primary glial cells were isolated from new suckling Wistar mice within $24 \mathrm{~h}$ of birth using the method of McCarthy and de Vellis [20]. The cell concentration was adjusted to $5 \times 10^{5}$ cells $/ \mathrm{ml}$ in $15 \%$ DMEM. The fourth generation (after about 20 days of culture) was used. The cells were maintained at $37{ }^{\circ} \mathrm{C}, 95 \%$ air and $5 \% \mathrm{CO}_{2}$ in a humidified incubator (Heraeus).

\section{Determination of cell viability}

To test cell viability, cell suspensions of $2 \times 10^{5}$ cells $/ \mathrm{ml}$ were mixed with $0.4 \%$ trypan blue. After 5-10 min, dye exclusion was examined for viable cells under a light microscope. The 3-(4,5-dimethylthiazol-2-yl)-2,5-diphenyltetrazolium bromide (MTT) bromide assay was also used to determine the number of viable cells after exposure to $\mathrm{As}_{2} \mathrm{O}_{3} .200 \mu \mathrm{l}$ cell suspensions $\left(4 \times 10^{4}\right.$ cells $\left./ \mathrm{ml}\right)$ were seeded in 96-well plates. Serially diluted $\mathrm{As}_{2} \mathrm{O}_{3}$ was added at final concentrations of 0 (control), 0.5, 1.0, 3.0, 5.0, 6.0, 7.0 and $8.0 \mu \mathrm{mol} / \mathrm{l}$. Each experiment was performed in quadruplicate and repeated at least three times. After 24, 48 and $72 \mathrm{~h}$, the MTT products were quantified and the results were presented as the percentage of viable cells and normalized to the level of controls. The optimal concentration was determined as $5.0 \mu \mathrm{mol} / \mathrm{l}$ and used to treat the rat C6 and $9 \mathrm{~L}$ cells. 


\section{Measurement of apoptosis}

After cultured for 24, 48 and $72 \mathrm{~h}$, cell apoptosis was assessed using propidium iodide (PI) and annexin-V conjugated to fluorescein isothiocyanate (FITC) according to the manufacturer's instructions (BD Biosciences). Briefly, cells with or without $\mathrm{As}_{2} \mathrm{O}_{3}$ were incubated with FITC-conjugated annexin-V. Then, the cells were collected, washed and centrifuged at $200 \mathrm{~g}$ for $10 \mathrm{~min}$. The cell pellet was gently resuspended in $200 \mu \mathrm{l} \mathrm{PI}$ and incubated in the dark for $30 \mathrm{~min}$ at room temperature. Apoptosis was then assessed using flow cytometry.

Cell apoptosis and necrosis were further examined by staining with Hoechst 33,342 (HOE) and PI, respectively. Cells were plated into 96-well plates and treated with $5.0 \mu \mathrm{mol} / \mathrm{l} \mathrm{As}_{2} \mathrm{O}_{3}$ for 24,48 and $72 \mathrm{~h}$. Cells $\left(5 \times 10^{6}\right.$ cells $\left./ \mathrm{ml}\right)$ were incubated for $15 \mathrm{~min}$ at $37{ }^{\circ} \mathrm{C}$ with $\mathrm{HOE}(10 \mu \mathrm{g} / \mathrm{ml}$ in PBS$)$, centrifuged, washed in PBS, and resuspended at density of $1 \times 10^{7}$ cells $/ \mathrm{ml}$. PI (50 $\mathrm{\mu g} / \mathrm{ml}$ in PBS) was added before observation. Cells were examined using a light microscope (Olympus) equipped with a fluorescent light source and a UV-2A filter cube with an excitation wavelength of 330-380 nm and a barrier filter of $420 \mathrm{~nm}$. All experiments were repeated at least three times.

\section{Measurement of ROS levels}

The generation of ROS was measured as previously described [21]. Briefly, cell suspensions $\left(2 \times 10^{6}\right.$ cells $\left./ \mathrm{ml}\right)$ were exposed to $\mathrm{As}_{2} \mathrm{O}_{3}$ at $5.0 \mu \mathrm{mol} / \mathrm{l}$ for 24,48 and $72 \mathrm{~h}$. To evaluate the major organelles that governed the ROS-mediated stress in glioma cells, C6 and $9 \mathrm{~L}$ cells were pretreated with $5 \mathrm{nM}$ antioxidant $\mathrm{N}$-acetylcysteine (NAC) for $2 \mathrm{~h}$, and were exposed to $\mathrm{As}_{2} \mathrm{O}_{3}$ at $5.0 \mu \mathrm{mol} / \mathrm{l}$ for $24 \mathrm{~h}$ [22]. After exposure, cells were incubated in $10 \mu \mathrm{M}$ of $2^{\prime}, 7^{\prime}$-dichlorofluorescein diacetate (DCFH-DA; Molecular Probes) at $37{ }^{\circ} \mathrm{C}$ for $30 \mathrm{~min}$. The cells were harvested and washed with cold PBS three times. Then, ROS levels were determined through fluorescence-activated cell sorting.

\section{Measurement of apoptotic proteins}

Levels of apoptosis-related proteins (Bcl-2, Bax and Fas) were analyzed using Western blot as previously described [23]. Briefly, cells were lysed at $4{ }^{\circ} \mathrm{C}$ via RIPA. Proteins were separated using 10\% SDS-PAGE, transferred to nitrocellulose membranes and incubated with primary antibodies against Bcl-2, Bax, Fas and actin (1:100, Santa Cruz Biotechnology). Then, the membranes were incubated with horseradish peroxidase-conjugated secondary antibodies, and detected using an enhanced chemiluminescence (ECL) kit (Beyotime).

\section{Statistical analysis}

All quantitative data measurements were performed in triplicate and the results are presented as means \pm standard deviation. One-way analysis of variance (ANOVA) was performed. The post hoc tests were Dunnett's tests. Probability values (p) less than 0.05 were considered statistically significant.

\section{Results}

\section{$\mathrm{As}_{2} \mathrm{O}_{3}$ decreased cell viability in $\mathrm{C} 6$ and $9 \mathrm{~L}$ glioma cells}

The cytotoxicity of $\mathrm{As}_{2} \mathrm{O}_{3}$ in $\mathrm{C} 6$ and $9 \mathrm{~L}$ cells was assessed using the MTT and trypan blue assays. $\mathrm{As}_{2} \mathrm{O}_{3}$ was applied at 0.5, 1.0, 3.0, 5.0, 6.0, 7.0 and $8.0 \mu \mathrm{mol} / \mathrm{l}$, and the 
inhibitory rates were determined after 24, 48 and $72 \mathrm{~h}$ (Fig. 1). The MTT assay showed that the $\mathrm{As}_{2} \mathrm{O}_{3}$-induced inhibitory rates for $\mathrm{C} 6$ and $9 \mathrm{~L}$ cells were dose and time dependent (Fig. 1a). The inhibitory effects of $\mathrm{As}_{2} \mathrm{O}_{3}$ on $\mathrm{C} 6$ and $9 \mathrm{~L}$ cells were significantly stronger than on normal glial cells. For example, the inhibition rate for normal glial cells exposed to $5.0 \mu \mathrm{mol} / \mathrm{l} \mathrm{As}_{2} \mathrm{O}_{3}$ was less than $10 \%$ of that for glioma cells, suggesting that $\mathrm{As}_{2} \mathrm{O}_{3}$ inhibited the growth of glioma cells but not normal glial cells in range of $0-8 \mu \mathrm{mol} / \mathrm{l}$. The calculated $\mathrm{IC}_{50}$ values for $\mathrm{C} 6$ and $9 \mathrm{~L}$ cells were respectively 5.0 and $5.6 \mu \mathrm{mol} / 1 \mathrm{As}_{2} \mathrm{O}_{3}$, so $5.0 \mu \mathrm{mol} / \mathrm{l} \mathrm{As}_{2} \mathrm{O}_{3}$ was used in the following experiments.

The trypan blue assay showed that $5.0 \mu \mathrm{mol} / 1 \mathrm{As}_{2} \mathrm{O}_{3}$ significantly decreased cell viabilities in $\mathrm{C} 6$ and $9 \mathrm{~L}$ in a time-dependent manner (Fig. 1b). Although the cell viability in normal glial cells was also significantly decreased, the change was smaller than for glioma cells, suggesting a greater inhibitory role in glioma than in glial cells.

\section{$\mathrm{As}_{2} \mathrm{O}_{3}$ induced apoptosis in $\mathrm{C} 6$ and $9 \mathrm{~L}$ glioma cells}

An annexin V-FITC/PI assay was used to assess cell apoptosis of glioma cells after exposure to $5 \mu \mathrm{M} \mathrm{As} \mathrm{O}_{3}$. The numbers of early (annexin V+/PI-) and late (annexin V + / PI+) apoptotic cells were calculated. In both C6 and 9 L glioma cells, apoptosis (seen as both early and late apoptotic cells) was significantly induced by $5 \mu \mathrm{M} \mathrm{As}_{2} \mathrm{O}_{3}$ in a time-dependent manner (Fig. 2a and b). The maximal percentages of apoptotic cells in both cell lines were reached at 72 h (14.35\% of C6 cells, and 13.13\% of 9 L cells; Fig. 2). However, the apoptotic rate for glial cells was only $3.59 \%$ (Fig. $2 \mathrm{c}$ and d). For cells without $\mathrm{As}_{2} \mathrm{O}_{3}$ treatment, the apoptosis rate was close to 0 (data not shown).

The apoptosis in glial and glioma cells after exposure to $5 \mu \mathrm{M}$ of $\mathrm{As}_{2} \mathrm{O}_{3}$ for $72 \mathrm{~h}$ was further confirmed with HOE/PI double staining (Fig. 3). Cell uptake of PI indicated necrosis. Cells with clear nuclear condensation but no PI uptake indicated apoptosis. After exposure to $\mathrm{As}_{2} \mathrm{O}_{3}$ for $72 \mathrm{~h}, \mathrm{C} 6$ and $9 \mathrm{~L}$ cells showed increases in both necrosis and apoptosis. The level of apoptosis and necrosis induced by $\mathrm{As}_{2} \mathrm{O}_{3}$ was higher in C6 and $9 \mathrm{~L}$ cells than in glial cells.

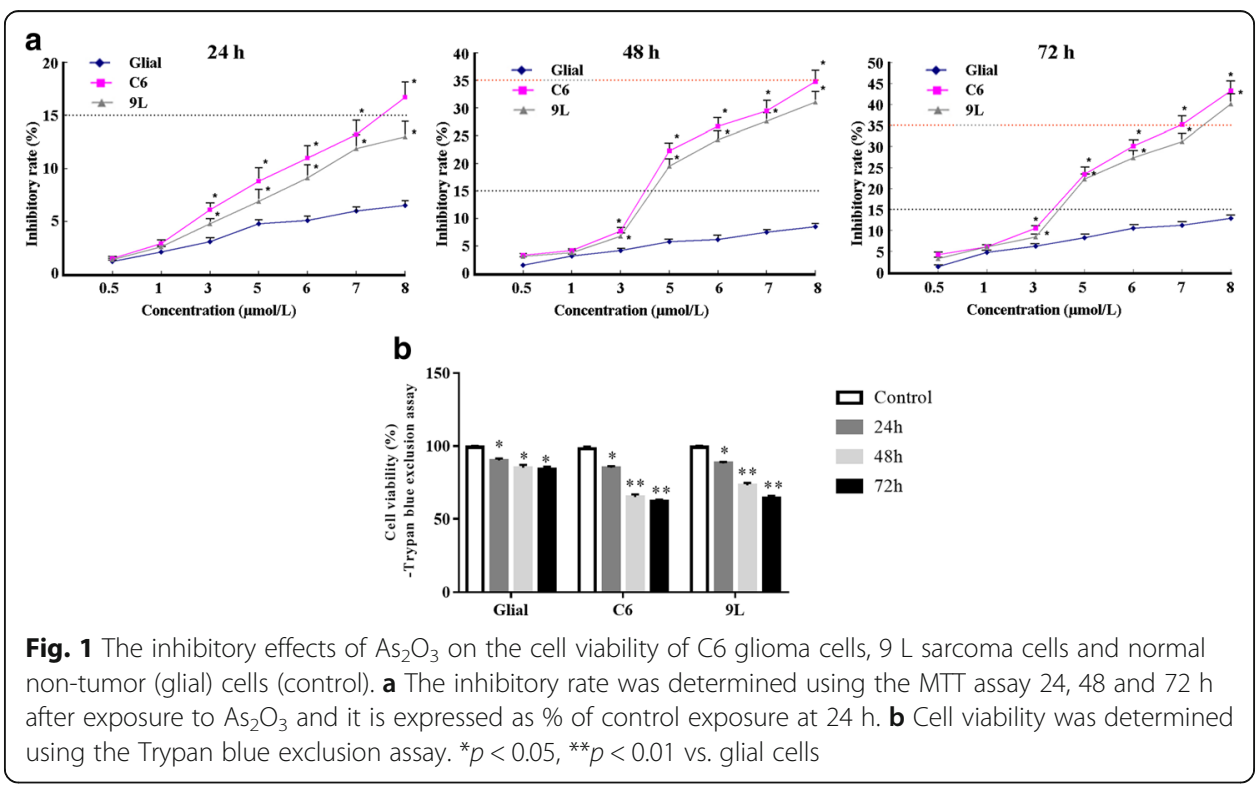




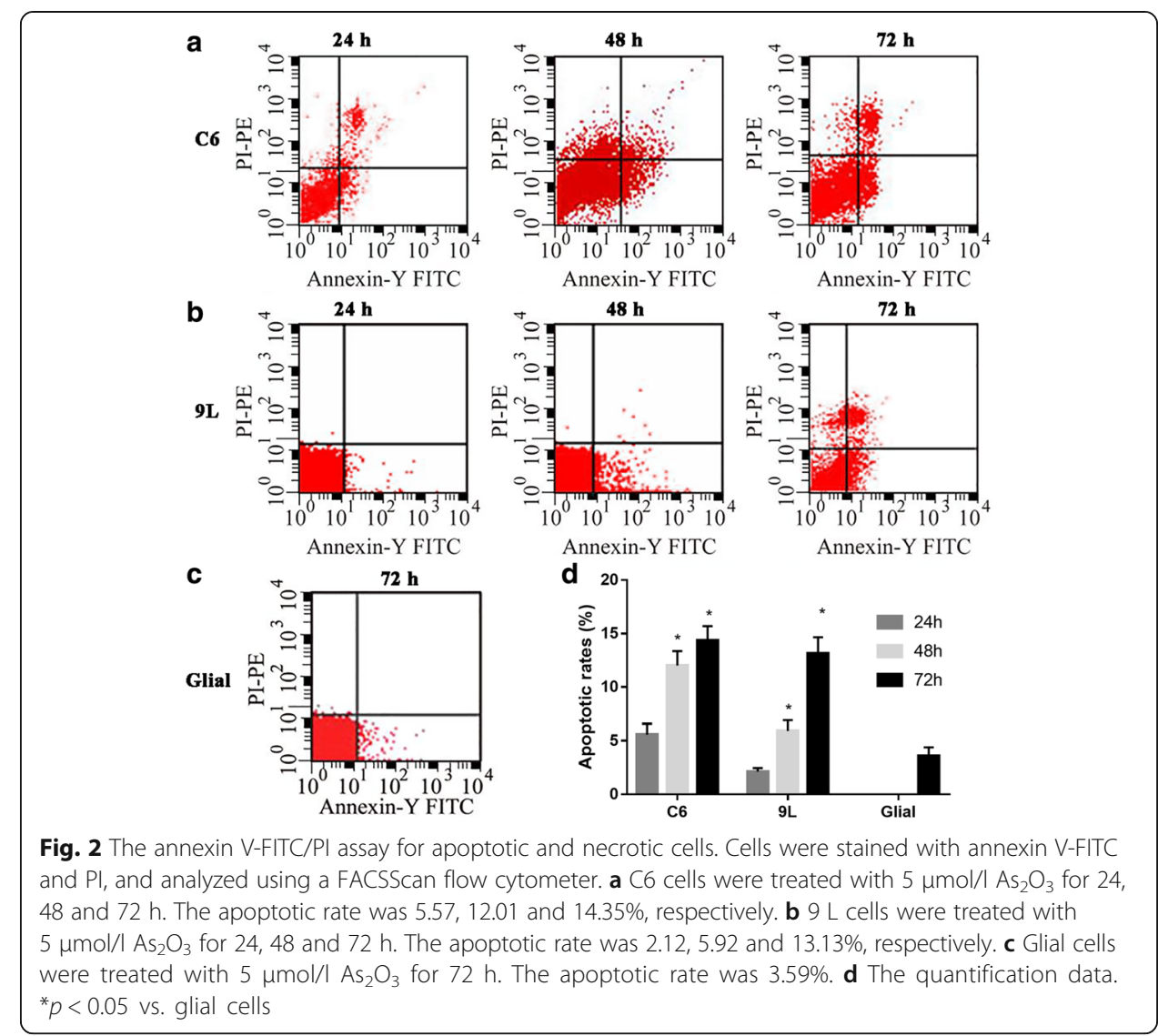

\section{Production of ROS in $\mathrm{C} 6$ and $9 \mathrm{~L}$ glioma cells exposed to $\mathrm{As}_{2} \mathrm{O}_{3}$}

The extent of cellular oxidative stress in living cells was estimated by monitoring ROS generation using the fluorescent dye DCFH-DA (Fig. 4). The mean fluorescence intensity in C6 cells was $7.58,200.37,344.80$ and 501.74 at $0,24,48$ and $72 \mathrm{~h}$, respectively. The mean fluorescence intensity in 9 L cells was 3.01, 180.27, 248.32 and 485.90 at 0, 24, 48 and $72 \mathrm{~h}$, respectively. Thus, the level of ROS level positively correlates with DCF intensity. In both C6 (Fig. 4a and b) and $9 \mathrm{~L}$ (Fig. 4b and c) cells, intracellular ROS increased significantly with increasing incubation time with $5 \mu \mathrm{mol} / \mathrm{l} \mathrm{As}_{2} \mathrm{O}_{3}(p<0.01)$. Cells pretreated with NAC significantly inhibited the increase in ROS in response to $24 \mathrm{~h}$ exposure to $\mathrm{As}_{2} \mathrm{O}_{3}$ (Fig. $4 \mathrm{a}$ and b).

\section{Effects of $\mathrm{As}_{2} \mathrm{O}_{3}$ on the expression of apoptotic proteins $\mathrm{Bcl}-2$, Bax and Fas}

To validate the apoptosis process, the expression levels of apoptosis markers, including $\mathrm{Bcl}-2$, Bax and Fas, were examined in $\mathrm{C} 6$ and $9 \mathrm{~L}$ glioma cells using western blotting. $\mathrm{As}_{2} \mathrm{O}_{3}$ significantly inhibited expression of the anti-apoptotic gene Bcl-2 and upregulated the pro-apoptotic gene Bax in both $\mathrm{C} 6$ and $9 \mathrm{~L}$ glioma cells in a time-dependent manner (Fig. 5a and b). The expression of Fas did not significantly change after exposure to $\mathrm{As}_{2} \mathrm{O}_{3}$ (Fig. $5 \mathrm{a}$ and $\mathrm{b}$ ).

\section{Discussion}

Because of its ability to induce apoptosis in various malignant tumor cells, $\mathrm{As}_{2} \mathrm{O}_{3}$ has potential as a treatment agent for malignant tumors [24, 25]. Gliomas are highly 


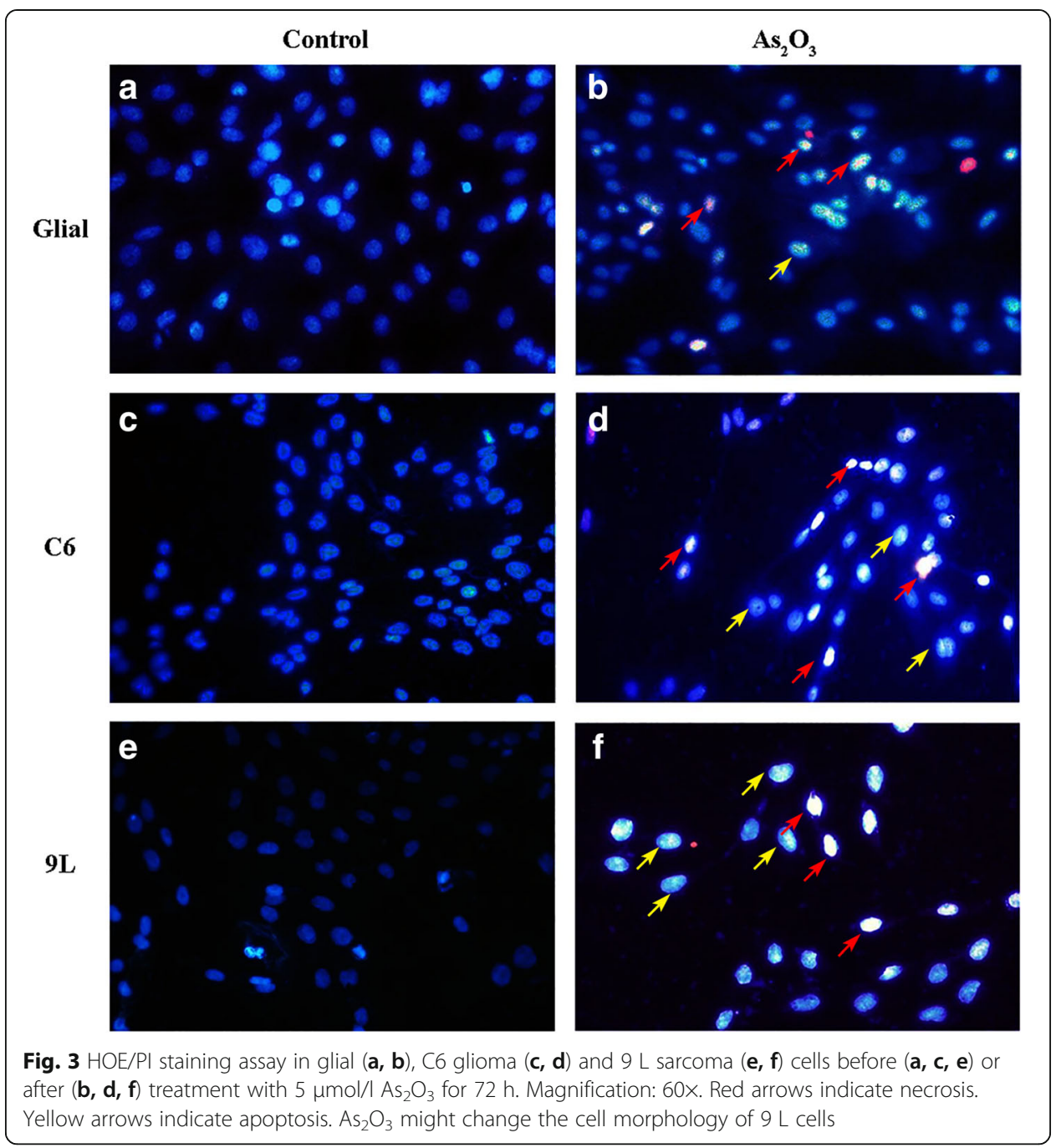

aggressive tumors that respond poorly to existing clinical therapeutic agents. In previous studies, it was shown that $\mathrm{As}_{2} \mathrm{O}_{3}$ treatment could inhibit cell growth of glioma cells, but the studies did not yield guidance on the effective doses [26-28].

Here, we investigated the effective doses of $\mathrm{As}_{2} \mathrm{O}_{3}$ using rat glioma cells and comparing them with non-tumor glial cells. Our results showed that $\mathrm{As}_{2} \mathrm{O}_{3}$ inhibited the growth of glioma cells in time- and concentration-dependent manners, and that $5.0 \mu \mathrm{mol} / \mathrm{l} \mathrm{As}_{2} \mathrm{O}_{3}$ is the optimum concentration for inhibiting cell viability in both $\mathrm{C} 6$ and $9 \mathrm{~L}$ glioma cells. The inhibitory rate for non-tumor cells was less than $10 \%$ of that for the glioma cells, indicating that $\mathrm{As}_{2} \mathrm{O}_{3}$ is a promising drug. Due to the exist of the blood-brain barrier, it remains unclear how the $5 \mu \mathrm{mol} / \mathrm{l}$ concentration can be obtained in human blood such that it would be useful for treating glioma cells. Further studies using in vivo animal models are needed.

Both the HOE/PI and annexin-V/PI assays showed that $5.0 \mu \mathrm{M} \mathrm{As} \mathrm{O}_{2} \mathrm{O}_{3}$ induced apoptosis. However, the mechanism of apoptosis in solid tumor cells is far from clear. In glioma cells treated with $\mathrm{As}_{2} \mathrm{O}_{3}$, one of the most likely mechanisms for triggering an antitumor effect is the induction of ROS [29, 30]. Like other heavy metals, including iron, copper, chromium, cadmium, lead and mercury, arsenic affects cells by causing 


oxidative damage, primarily through disruption of the endogenous cellular antioxidant-redox balance $[29,30]$. Cysteine thiol is the functional site for most redox proteins. Arsenic can directly bind to this site and destroy protein function, thereby affecting ROS production and clearance [29, 30]. Cell viability, ROS levels, apoptosis and autophagy in human glioblastoma cell line have been shown to be regulated by $\mathrm{As}_{2} \mathrm{O}_{3}$ [31, 32] and/or $\mathrm{As}_{2} \mathrm{O}_{3}$ in combination with other agents [33]. $\mathrm{As}_{2} \mathrm{O}_{3}$ induces ROS production and apoptosis in glioma cells through the upregulation of the mitoferrin-2 gene [34]. Consistently with the results of those studies, we also found that intracellular ROS levels increased significantly after $\mathrm{As}_{2} \mathrm{O}_{3}$ treatment.

The brain appears to be especially sensitive to ROS stress when compared to other organs. Although comprising only $2 \%$ of human body weight, the human brain consumes up to $20 \%$ of the oxygen supply. Such a high level of oxygen consumption indicates that large quantities of ROS are generated during oxidative phosphorylation in brain tissue. In addition, iron content has been shown to increase brain sites in which ROS production may be greater [35]. Tumor cells are vulnerable to ROS stress. Thus, therapeutic approaches directed at ROS intervention may have an antitumor effect, and $\mathrm{As}_{2} \mathrm{O}_{3}$ is a promising antitumor reagent for gliomas.

$\mathrm{As}_{2} \mathrm{O}_{3}$ downregulated the expression of Bcl-2, an anti-apoptotic protein, and upregulated the expression of Bax, a pro-apoptotic protein, thus shifting the $\mathrm{Bax} / \mathrm{Bcl}-2$ ratio in favor of apoptosis. Fas protein expression remained unchanged. These findings indicate that $\mathrm{Bcl}-2$ and Bax play an important role in $\mathrm{As}_{2} \mathrm{O}_{3}$-induced apoptosis in $\mathrm{C} 6$ and $9 \mathrm{~L}$ glioma cells.

Our results hinted at the possible involvement of mitochondrial dysfunction in $\mathrm{As}_{2} \mathrm{O}_{3}$-induced apoptosis. The Bcl-2 family of proteins appear to control cell death by regulating mitochondrial physiology [36]. A change in the mitochondrial electrochemical potential results in the release of apoptotic proteins, such as cytochrome c, Smac/ DIABLO, pro-caspases 2, 3 and 9, and apoptosis-inducing factor.

Under physiological and pathophysiological conditions, ROS contributes to trigger and mediate apoptosis [37]. The mitochondria are highly susceptible to oxidative damage, and $\mathrm{Bcl}-2$ exerts its anti-apoptotic function by reducing intracellular ROS. $\mathrm{As}_{2} \mathrm{O}_{3}$ downregulated Bcl-2 and rendered $\mathrm{C} 6$ and $9 \mathrm{~L}$ glioma cells vulnerable to apoptotic cell death. In cells pretreated with $\mathrm{NAC}, \mathrm{As}_{2} \mathrm{O}_{3}$-induced apoptosis was inhibited, suggesting that a mitochondrial death pathway plays an important role in $\mathrm{As}_{2} \mathrm{O}_{3}$-induced apoptosis.

\section{Conclusion}

$\mathrm{As}_{2} \mathrm{O}_{3}$ strongly inhibits cell viability and induces apoptosis of rat $\mathrm{C} 6$ and $9 \mathrm{~L}$ glioma cells in vitro when used at an optimal concentration of $5 \mu \mathrm{mol} / \mathrm{l}$. This action is related to the induction of ROS generation. Moreover, $\mathrm{As}_{2} \mathrm{O}_{3}$ showed lower cytotoxicity to normal glial cells than glioma cells, indicating that $\mathrm{As}_{2} \mathrm{O}_{3}$ may be a potentially potent chemotherapeutic agent for treating brain tumors.

\section{Abbreviations}

APL: Promyelocytic leukemia; $\mathrm{As}_{2} \mathrm{O}_{3}$ : Arsenic trioxide; DMEM: Dulbecco's modified Eagle's medium;

ECL: Enhanced chemiluminescence; FCS: Fetal calf serum; FITC: Fluorescein isothiocyanate; MTT: 3-(4,5dimethylthiazol-2-yl)-2,5-diphenyltetrazolium bromide; PBS: Phosphate buffered saline; PI: Propidium iodide; ROS: Reaction oxygen species 
Funding

This study was supported by the National Natural Science Foundation of China (Grant No. 30600641) and the Administration of Education, Heilongjiang Province (Grant No. 11511209).

Availability of data and materials

Please contact the author with data requests.

\section{Authors' contributions}

YS, CW, LW and ZD performed the experiments. All the authors contributed to the data analysis and manuscript preparation. All authors read and approved the final manuscript.

\section{Ethics approval and consent to participate}

Not applicable.

\section{Consent for publication}

Not applicable.

\section{Competing interests}

The authors declare that they have no competing interests.

\section{Publisher's Note}

Springer Nature remains neutral with regard to jurisdictional claims in published maps and institutional affiliations.

\section{Author details}

${ }^{1}$ Nursing Support Center, First Affiliated Hospital, Harbin Medical University, Harbin 150000 , China. ${ }^{2}$ Neurosurgery

Department, First Affiliated Hospital, Harbin Medical University, Nangang District, Harbin 150000, China.

Received: 20 September 2017 Accepted: 8 February 2018

Published online: 27 March 2018

\section{References}

1. Mervis J. Ancient remedy performs new tricks. Science. 1996;273:578.

2. Nellessen CM, Janzen V, Mayer K, Giovannini G, Gembruch U, Brossart P, Merz WM. Successful treatment of acute promyelocytic leukemia in pregnancy with single-agent all-trans retinoic acid. Arch Gynecol Obstet. 2017; https:// doi.org/10.1007/s00404-017-4583-6.

3. Hassani S, Khaleghian A, Ahmadian S, Alizadeh S, Alimoghaddam K, Ghavamzadeh A, Ghaffari SH. Redistribution of cell cycle by arsenic trioxide is associated with demethylation and expression changes of cell cycle related genes in acute promyelocytic leukemia cell line (NB4). Ann Hematol. 2017; https://doi.org/10.1007/s00277-017-3163-y.

4. Chen GQ, Zhu J, Shi XG, Ni JH, Zhong HJ, Si GY, Jin XL, Tang W, Li XS, Xong SM, Shen ZX, Sun GL, Ma J, Zhang P, Zhang TD, Gazin C, Naoe T, Chen SJ, Wang ZY, Chen Z. In vitro studies on cellular and molecular mechanisms of arsenic trioxide (As2O3) in the treatment of acute promyelocytic leukemia: As2O3 induces NB4 cell apoptosis with downregulation of Bcl-2 expression and modulation of PML-RAR alpha/PML proteins. Blood. 1996;88:1052-61.

5. Chen GQ, Shi XG, Tang W, Xiong SM, Zhu J, Cai X, Han ZG, Ni JH, Shi GY, Jia PM, Liu MM, He KL, Niu C, Ma J, Zhang P, Zhang TD, Paul P, Naoe T, Kitamura K, Miller W, Waxman S, Wang ZY, De The H, Chen SJ, Chen Z. Use of arsenic trioxide (As2O3) in the treatment of acute promyelocytic leukemia (APL): I. As2O3 exerts dose-dependent dual effects on APL cells. Blood. 1997;89:3345-53.

6. Zhang P, Zhao X, Zhang W, He A, Lei B, Zhang W, Chen Y. Leukemia-associated gene MLAA-34 reduces arsenic trioxide-induced apoptosis in HeLa cells via activation of the Wnt/beta-catenin signaling pathway. PLoS One. 2017;12:e0186868. https://doi.org/10.1371/journal.pone.0186868.

7. Zhang F, Zhang CM, Li S, Wang KK, Guo BB, Fu Y, Liu LY, Zhang Y, Jiang HY, Wu CJ. Low dosage of arsenic trioxide inhibits vasculogenic mimicry in hepatoblastoma without cell apoptosis. Mol Med Rep. 2018;17:1573-82 https://doi.org/10.3892/mmr.2017.8046.

8. Zeng Y, Liu X, Yan Z, Xie L. Sphingosine 1-phosphate regulates proliferation, cell cycle and apoptosis of hepatocellular carcinoma cells via syndecan-1. Prog Biophys Mol Biol. 2017; https://doi.org/10.1016/.jpbiomolbio. 2017.11.006.

9. Wang GB, Liu JH, Hu J, Xue K. Mechanism of As2O3 induces apoptosis of glioma U87 cells. Eur Rev Med Pharmacol Sci. 2017;21:4875-81.

10. Pan L, Li Y, Zhang HY, Zheng Y, Liu XL, Hu Z, Wang Y, Wang J, Cai YH, Liu Q, Chen WL, Guo Y, Huang YM, Oian F, Jin L, Wang J, Wang SY. DHX15 is associated with poor prognosis in acute myeloid leukemia (AML) and regulates cell apoptosis via the NF-kB signaling pathway. Oncotarget. 2017:8:89643-54. https://doi.org/10.18632/oncotarget. 20288.

11. Jing Y, Dai J, Chalmers-Redman RM, Tatton WG, Waxman Arsenic S. Trioxide selectively induces acute promyelocytic leukemia cell apoptosis via a hydrogen peroxide-dependent pathway. Blood. 1999;94:2102-11.

12. Yi J, Yang J, He R, Gao F, Sang H, Tang X, Ye RD. Emodin enhances arsenic trioxide-induced apoptosis via generation of reactive oxygen species and inhibition of survival signaling. Cancer Res. 2004;64:108-16.

13. Maeda H, Hori S, Nishitoh H, Ichijo H, Ogawa O, Kakehi Y, Kakizuka Tumor A. Growth inhibition by arsenic trioxide (As2O3) in the orthotopic metastasis model of androgen-independent prostate cancer. Cancer Res. 2001:61:5432-40.

14. Kajiguchi T, Yamamoto K, Hossain K, Akhand AA, Nakashima I, Naoe T, Saito H, Emi Sustained N. Activation of cjun-terminal kinase (JNK) is closely related to arsenic trioxide-induced apoptosis in an acute myeloid leukemia (M2)-derived cell line, NKM-1. Leukemia. 2003;17:2189-95. https://doi.org/10.1038/sj.leu.2403120. 
15. Cheng Y, Li Y, Ma C, Song Y, Xu H, Yu H, Xu S, Mu Q, Li H, Chen Y, Zhao G. Arsenic trioxide inhibits glioma cell growth through induction of telomerase displacement and telomere dysfunction. Oncotarget. 2016;7:12682-92. https://doi.org/10.18632/oncotarget.7259.

16. Xia ZB, Wu XJ, Qi TW, Huang ZS. Study on inhibitory effect of arsenic trioxide on growth of rat C6 glioma cells. Zhongguo Zhong Yao Za Zhi. 2008;33:2150-3.

17. Xu Y, Zhang Y, Liu X, Wang Z, Ma J, Wang J, Yue The W. Effects of ultrasound and arsenic trioxide on neurogliocytoma cells and secondary activation of macrophages. Tumori. 2009;95:780-8.

18. Barbey JT, Pezzullo JC, Soignet SL. Effect of arsenic trioxide on QT interval in patients with advanced malignancies. J Clin Oncol. 2003;21:3609-15. https://doi.org/10.1200/JCO.2003.10.009.

19. Huang SY, Chang CS, Tang JL, Tien HF, Kuo TL, Huang SF, Yao YT, Chou WC, Chung CY, Wang CH, Shen MC, Chen YC. Acute and chronic arsenic poisoning associated with treatment of acute promyelocytic leukaemia. $\mathrm{Br} J$ Haematol. 1998;103:1092-5.

20. McCarthy KD, de Vellis J. Preparation of separate astroglial and oligodendroglial cell cultures from rat cerebral tissue. J Cell Biol. 1980;85:890-902.

21. Tan Z, Jia X, Ma F, Feng Y, Lu H, Jin JO, Wu D, Yin L, Liu L, Zhang L. Increased MMAB level in mitochondria as a novel biomarker of hepatotoxicity induced by Efavirenz. PLoS One. 2017;12:e0188366. https://doi.org/10.1371/ journal.pone.0188366.

22. Yi D, Hou Y, Xiao H, Wang L, Zhang Y, Chen H, Wu T, Ding B, Hu CA, Wu G. N-acetylcysteine improves intestinal function in lipopolysaccharides-challenged piglets through multiple signaling pathways. Amino Acids. 2017;49: 1915-29. https://doi.org/10.1007/s00726-017-2389-2.

23. Zeng Y, Yao X, Chen L, Yan Z, Liu J, Zhang Y, Feng T, Wu J, Liu X. Sphingosine-1-phosphate induced epithelialmesenchymal transition of hepatocellular carcinoma via an MMP-7/ syndecan-1/TGF-beta autocrine loop. Oncotarget. 2016;7:63324-37. https://doi.org/10.18632/oncotarget.11450.

24. Klinger PH, Andrade AF, Delsin LE, Queiroz RG, Scrideli CA, Tone LG, Valera ET. Inhibition of SHH pathway mechanisms by arsenic trioxide in pediatric medulloblastomas: a comprehensive literature review. Genet Mol Res. 2017;16 https://doi.org/10.4238/gmr16019412.

25. Chang HR, Munkhjargal A, Kim MJ, Park SY, Jung E, Ryu JH, Yang Y, Lim JS, Kim Y. The functional roles of PML nuclear bodies in genome maintenance. Mutat Res. 2017; https://doi.org/10.1016/j.mrfmmm.2017.05.002.

26. Zhao S, Tsuchida T, Kawakami K, Shi C, Kawamoto K. Effect of As2O3 on cell cycle progression and cyclins D1 and B1 expression in two glioblastoma cell lines differing in p53 status. Int J Oncol. 2002;21:49-55.

27. Akao Y, Nakagawa Y, Akiyama K. Arsenic trioxide induces apoptosis in neuroblastoma cell lines through the activation of caspase 3 in vitro. FEBS Lett. 1999;455:59-62. S0014-5793(99)00841-8

28. Kanzawa T, Kondo Y, Ito H, Kondo S, Germano I. Induction Of autophagic cell death in malignant glioma cells by arsenic trioxide. Cancer Res. 2003;63:2103-8.

29. Chakraborti T, Das S, Mondal M, Roychoudhury S, Chakraborti S. Oxidant Mitochondria and calcium: an overview. Cell Signal. 1999;11:77-85. S0898-6568(98)00025-4

30. Forman HJ, Torres Reactive M. Oxygen species and cell signaling: respiratory burst in macrophage signaling. Am J Respir Crit Care Med. 2002;166:S4-8. https://doi.org/10.1164/rccm.2206007 166/12 Pt 2/S4.

31. Pucer A, Castino R, Mirkovic B, Falnoga I, Slejkovec Z, Isidoro C, Lah TT. Differential Role of cathepsins B and L in autophagy-associated cell death induced by arsenic trioxide in U87 human glioblastoma cells. Biol Chem. 2010; 391:519-31. https://doi.org/10.1515/bc.2010.050.

32. Primon M, Huszthy PC, Motaln H, Talasila KM, Torkar A, Bjerkvig R, Lah Turnsek T. Cathepsin L silencing enhances arsenic trioxide mediated in vitro cytotoxicity and apoptosis in glioblastoma U87MG spheroids. Exp Cell Res. 2013; 319:2637-48. https://doi.org/10.1016/j.yexcr.2013.08.011.

33. Klauser E, Gulden M, Maser E, Seibert S, Seibert H. Additivity, antagonism, and synergy in arsenic trioxide-induced growth inhibition of C6 glioma cells: effects of genistein, quercetin and buthionine-sulfoximine. Food Chem Toxicol. 2014;67:212-21. https://doi.org/10.1016/j.fct.2014.02.039.

34. Wang C, Chen X, Zou H, Chen X, Liu Y, Zhao S. The roles of mitoferrin-2 in the process of arsenic trioxide-induced cell damage in human gliomas. Eur J Med Res. 2014;19:49. https://doi.org/10.1186/s40001-014-0049-5.

35. Gerlach M, Ben-Shachar D, Riederer P, Youdim MB. Altered Brain metabolism of iron as a cause of neurodegenerative diseases? J Neurochem. 1994;63:793-807.

36. Kitazawa H, Numakawa T, Adachi N, Kumamaru E, Tuerxun T, Kudo M, Kunugi H. Cyclophosphamide promotes cell survival via activation of intracellular signaling in cultured cortical neurons. Neurosci Lett. 2010;470:139-44. https:// doi.org/10.1016/j.neulet.2009.12.073. S0304-3940(09)01677-2

37. Bauer G. Reactive oxygen and nitrogen species: efficient, selective, and interactive signals during intercellular induction of apoptosis. Anticancer Res. 2000;20:4115-39. 